\title{
Articulation of High Order Thinking Skills in Competency-Based Instruction in Indonesia Vocational and Technical High School
}

\author{
Sutarto HP \\ Universitas Negeri Yogyakarta \\ Yogyakarta, Indonesia \\ sutarto@uny.ac.id
}

\begin{abstract}
The development of information and digital technologies demand employees who possess higher order thinking skills (HOTS). On the other side, under 2013 Curriculum that competence-based orientation, Vocational and Technical High School (SMK) in Indonesia as an institution that supply employee candidates has to bear graduates who achieve a certain number of competence standards. Based on supply-demand principle, therefore SMK curriculum needs to articulate HOTS in teaching and learning of vocational and technical subject matters. The objective of this paper is to discuss the concept and principles of competence-based instruction (CBI) and HOTS, then integrate HOTS in CBI in SMK. The discussion in this paper is done by reviewing related literatures, research findings, and facts happened in the fields. Implication, conclusion, and recommendations are presented at the end of this paper.
\end{abstract}

Keywords-competence based; curriculum; education; HOTS; vocational

\section{INTRODUCTION}

Reference [1] stated that the concept of competence has been introduced into Vocational and Technical Education and Training (VTET) programs to prepare young people even more specifically for the requirements of their future professional life. These not only encompass technical knowledge and skills but also self-reliance and social behavior. Declaration of the European Ministers of Vocational Education and Training in Copenhagen on 30 November 2002 enhanced European cooperation in vocational education and training to implement competence-based teaching and learning. It will lead VTET graduates to have recognition of competences, qualifications, and quality assurance. To implement competence-based approach in teaching and learning, VTET needs to be supported by main its stakeholders: employers, labor union, and government (tripartite) to design a VTET perspective curriculum, implement and monitor it to result employable graduates as well as productive citizen who will successfully participate in global workplace.
To have those intended graduate above, [2] described that graduates must equip themselves with knowledge and skills necessary to fulfill personal interests and goals, develop leadership skills, and become qualified and competent members of the workforce. More specific, facing The Fourth Industrial Revolution that dominated by digital technology and automation in the workforce. Reference [3] stated that at least 10 competencies needed by workers in 2020. Those competencies are complex problem solving, critical thinking, creativity, people management, coordinating others, emotional intelligence, and judgment decision making, service orientation, negotiation, and cognitive flexibility. Referring learning objective of Bloom's taxonomy, those competencies are categorized as high order thinking skills (HOTS): to analysis, to evaluate, and to create. Therefore, in addition to competence-based, VTET curriculum has to accommodate those HOTS.

In regards to Indonesian Context, 2013 Competence-Based Curriculum for Vocational and Technical High School has formally accommodated HOTS. Indonesia Minister of Education and Culture (MOEC) has formulated standard of teaching and learning process in class based 2013 Curriculum. To successfully implementing this curriculum, workshop, inhouse training, and other facilitations have been provided for most educational personnel and teachers. Teacher workbooks and student-package books have been distributed nationwide to schools. Now, the main question: Are VTET teachers able to articulate HOTS in their teaching and learning process relevant to competency-based instruction suggested in 2013 curriculum?

\section{A. Competence-Based Instruction}

Reference [4:6] stated that there was no single definition of Competency-Based Instruction (CBI), however it can be identified by four main characteristics. Those are: (1) spell out exactly what it is that trainees should learn; (2) provide high quality of instruction; (3) help students learn one thing well before going on to the next; and (4) require each trainee to demonstrate competency. Some experts call CBI concept by other names or title, such as Mastery Learning, System Approach to Education; Personalized System of Instruction (PSI); Performance-Based Instruction; Criterion-Referenced 
Instruction (CRI), Learning for Mastery (LFM); ObjectiveReferenced Learning; Individualized Instruction (II); Programmed Instruction; Self-peace Learning; and Instructional System Development (ISD).

Furthermore, [4] described that the basis of CBI is transformed from pioneers who wrote books to promote "mastery learning" teaching approach. They were, especially, John B. Carroll (1963) with A model of School Learning; James H. Block (1970) with Mastery Learning; and Benyamin S. Bloom (1976) with Human Characteristics and School Learning. Following are three philosophies stated by [5:72333].

1. A student's aptitude for a given subject could be defined in term of the amount of time he or she needs to learn the subject to a given level, rather than the level to which the subject would be learned in a given amount of time. That is, aptitude could be viewed as an index of learning rate, rather than learning level.

2. The degree of learning for any student in a school setting is $\mathrm{s}$ simple function of the time he or she actually spent in learning relative to the time he or she needs spend. Thus, to the extent that each student is allowed sufficient time to learn a given subject to some pre specified level, and he or she spends the time needed to learn, the student will likely learn the subject to the specified level.

3. In a school learning situation, the time a student actually spends learning a subject as well as the time he or she need to spend will be determined by certain instructional and personal characteristics. The two major instructional characteristics are student's opportunity to learn, and the quality of instruction. In addition to aptitude, the relevant personal characteristics are the student's ability to understand instruction and his or her perseverance.

According to [4], CBI relies on two basic philosophies. First is the notion that "human competence" is ability to actually perform. Knowledge, attitude, and effort are of little value without results. The second philosophy is inferred from three Carroll's mastery learning philosophies above that most anyone can learn most anything well if given quality instruction and sufficient time. CBI is best understood when contrasted with the elements of non-CBI as presented in Table 1 by [6].

TABLE 1. A Comparison of the Elements of Structure- and Process-based Versus Competency-based Educational Programs

\begin{tabular}{|c|c|c|}
\hline \multirow[b]{2}{*}{ Variables } & \multicolumn{2}{|c|}{ Educational Program } \\
\hline & Structure- and Process-based & Competency-based \\
\hline Driving force for curriculum & Responsibility for content & Responsibility for content \\
\hline Driving force for process & Teacher & Learner \\
\hline Path of learning & Hierarchical (teacher $\Rightarrow$ student) & Non-hierarchical (teacher $\Leftrightarrow$ student) \\
\hline Responsibility for content & Teacher & Teacher and students \\
\hline Goal of educational encounter & Knowledge acquisition & Knowledge application \\
\hline Typical assessment tool & Single subjective measure & $\begin{array}{l}\text { Multiple objective measures (" evaluation } \\
\text { portfolio") }\end{array}$ \\
\hline Assessment tool & Proxy & Authentic (mimics real tasks of profession) \\
\hline Setting for evaluation & Removed (gestalt) & "In the trenches", (direct observation) \\
\hline Evaluation & Norm-referenced & Criterion-referenced \\
\hline Timing of assessment & Emphasis on summative & Emphasis on formative \\
\hline Program completion & Fixed time & Variable time \\
\hline
\end{tabular}

Reference [4] contrasts the two teaching and learning approaches above in four primary different ways: what it is students learn, how they learn each task, when they proceed from task to task, and how we determine and report if students learn each task. At first glance, these differences seem to be minor, however when you think seriously about them in term of teaching strategies and class management the characteristics of the two approach as if day and night as presented in Table 2 .

TABLE 2. Basic Characteristics that Distinguish between Competency-Based Instruction (CBI) and Traditional Instructions

\begin{tabular}{|l|l|l|}
\hline \multicolumn{1}{|c|}{ Characteristics } & \multicolumn{1}{|c|}{ Competency-Based Instruction } & \multicolumn{1}{c|}{ Traditional Instruction } \\
\hline 1. WHAT Students Learn & $\begin{array}{l}\text { Based solely on specific, precisely stated student } \\
\text { outcomes (usually called competencies or task) that have } \\
\text { been recently verified as being essential for successful } \\
\text { employment in the occupation for which the student is } \\
\text { being trained. These competencies are made available to } \\
\text { all concerned and describe exactly what the student will } \\
\text { be able to do upon completing the training } \\
\text { program/semester. }\end{array}$ & $\begin{array}{l}\text { Are usually based on textbook, reference material, } \\
\text { course outline or other sources removed from the } \\
\text { occupation itself. Students rarely know exactly what } \\
\text { they will learn in each successive part of the } \\
\text { program/semester. The program is usually build } \\
\text { around chapters, units, blocks, and other segments } \\
\text { that have little meaning within the occupation. } \\
\text { Instructor focus on "covering material" }\end{array}$ \\
\hline 2. HOW Students Learn & $\begin{array}{l}\text { Provide students with high quality, carefully designed, } \\
\text { student-centered learning activities, media and material } \\
\text { designed to help them master each task. Materials are }\end{array}$ & $\begin{array}{l}\text { Really primarily on the instructor to personally } \\
\text { deliver most of the instruction through live } \\
\text { demonstration, lecturer, discussions and other }\end{array}$ \\
\hline
\end{tabular}




\begin{tabular}{|l|l|l|}
\hline \multicolumn{1}{|c|}{ Characteristics } & \multicolumn{1}{|c|}{ Competency-Based Instruction } & \multicolumn{1}{c|}{ Traditional Instruction } \\
\hline & $\begin{array}{l}\text { organized so that each individual student can stop, slow } \\
\text { down, speed up or repeat the instruction as needed to learn } \\
\text { effectively. Integral part of this instruction is periodic } \\
\text { feedback throughout the learning process with opportunity } \\
\text { for student to correct their performance as they go. }\end{array}$ & $\begin{array}{l}\text { instructor-centered learning activities. Students have } \\
\text { little control over the pace of instruction. Usually, } \\
\text { little periodic feedback on progress is given. }\end{array}$ \\
\hline $\begin{array}{l}\text { 3. WHEN Student } \\
\text { Proceed From Task To } \\
\text { Task }\end{array}$ & $\begin{array}{l}\text { Provide each trainee with enough time (within reason) to } \\
\text { fully master one task before being allowed or forced to } \\
\text { move on to the next. }\end{array}$ & $\begin{array}{l}\text { Usually require a group of students to spend the same } \\
\text { amount of time on each unit of instruction. The group } \\
\text { then moves on to the next unit after a fixed amount of } \\
\text { time which may too soon or not soon enough for } \\
\text { many individual students. }\end{array}$ \\
\hline $\begin{array}{l}\text { 4. IF Students Learn } \\
\text { Each Task }\end{array}$ & $\begin{array}{l}\text { Required each individual student to perform each task to a a } \\
\text { high level of proficiency in job like setting before } \\
\text { receiving credit for attaining each task. Performance is } \\
\text { compared to a preset, fixed standard. }\end{array}$ & $\begin{array}{l}\text { Rely heavy on paper and pencil test and each } \\
\text { student's performance is usually compared to the } \\
\text { group norm. Students are allowed (and usually } \\
\text { forced) to move on to the next unit after only } \\
\text { marginally mastering or even "failing" the current } \\
\text { unit. }\end{array}$ \\
\hline
\end{tabular}

Since CBI appear to be some benefits to learners, e.g., student centered, employability oriented, well designed instruction including authentic assessment, therefore teachers and educational personnel need to understand fully basic principles in administering CBI. Reference [7] explained the following basic principles and characteristics of CBI which are: (1) competencies are to be specified in behavioral terms and made public; (2) assessment criteria are competencybased and specify what constitutes mastery level of achievement; (3) assessment requires performance as the prime evidence but also takes knowledge into account; (4) individual learners progress at rates dependent on demonstrated competency; (5) the instructional program facilitates development and evaluation of the specific competencies. Furthermore, [7] explained main characteristics of CBI: (1) learning is individualized; ( 2 feedbacks to the learner are critical; (3) emphasis is more on the exit criteria than on the admission criteria; (4) CBI requires a systematic program (approach); (5) training is modularized; (6) both the learner and the program have accountability.

More specific and detail, [4] described seven basic principles of $\mathrm{CBI}$ as follows.

1. Any student in a training program (class) can master most any task at a high level of mastery (90-100\% proficiency) if provided with high quality instruction and sufficient time.

2. A student's ability for learning a task need not predict how well the student learns the task.
3. Individual student differences in level of mastery of a task are caused primarily by errors in the training/class environment, not by characteristics of the students.

4. Rather than being fast or slow learners, or good or poor learners, most students become very similar to one another in learning ability, rate of learning, and motivation for further learning when provided with favorable learning conditions.

5. We need focus more on differences in learning and less in learners.

6. What is worth teaching is worth learning.

7. The most important element in the teaching-learning process is the kind and quality of instruction experienced by students.

There are benefits will be ripped by implementing CBI Followings are the advantages stated by [8:2] are: (1) participants will achieve competencies required in the performance of their jobs; (2) participants build confidence as they succeed in mastering specific competencies; (3) participants receive a transcript or list of the competencies they have achieved; (4) training time is used more efficiently and effectively as the trainer is a facilitator of learning as opposed to a provider of information; (5) more training time is devoted to working with participants individually or in small groups as opposed to presenting lectures; (6) more training time is devoted to evaluating each participant's ability to perform essential job skills.

Reference [9] depicted a wider spectrum (4 out of 9) of the advantages by contrasting traditional approaches and CBI as presented in Table 3.

TABLE 3. Contrasts between traditional Approach and CBI and Its Advantages

\begin{tabular}{|c|c|c|c|}
\hline Aspects & Traditional Approaches & CBE/T Approaches & Perceived Advantages \\
\hline $\begin{array}{l}\text { 1. Register } \\
\text { credentials }\end{array}$ & $\begin{array}{l}\text { - Series of credentials in each } \\
\text { State/Territory, often with little } \\
\text { relationship to each other. } \\
\text { - Similar credentials often known } \\
\text { under different names. }\end{array}$ & $\begin{array}{l}\text { Credentials are registered and } \\
\text { recognized nationally.. }\end{array}$ & $\begin{array}{l}\text { - National consistency in the } \\
\text { meaning of credentials. } \\
\text { - Credentials are fully portable } \\
\text { through nationwide. }\end{array}$ \\
\hline $\begin{array}{l}\text { 2. Proof of } \\
\text { competency }\end{array}$ & $\begin{array}{l}\text { - Credentials indicates holder has } \\
\text { successfully completed a }\end{array}$ & $\begin{array}{l}\text { - Credentials indicate holder has } \\
\text { achieve specific competencies }\end{array}$ & $\begin{array}{l}\text { - Credentials certify holder's } \\
\text { ability to do a range of jobs. }\end{array}$ \\
\hline
\end{tabular}




\begin{tabular}{|c|c|c|c|}
\hline Aspects & Traditional Approaches & CBE/T Approaches & Perceived Advantages \\
\hline & $\begin{array}{l}\text { course, but do not indicate level } \\
\text { of competency. }\end{array}$ & to specific standards & \\
\hline 3. Accreditation & $\begin{array}{l}\text { - Accreditation process is } \\
\text { different for each State } \\
\text { /Territory. }\end{array}$ & $\begin{array}{l}\text { Accreditation is by a single } \\
\text { authority, recognize in each } \\
\text { State/Territory. }\end{array}$ & $\begin{array}{l}\text { - One process to gain national } \\
\text { recognition of credentials } \\
\text { instead of a number of States. }\end{array}$ \\
\hline $\begin{array}{l}\text { 4. National } \\
\text { standards }\end{array}$ & $\begin{array}{l}\text { - Curriculum is based on the time } \\
\text { spent in the training and the } \\
\text { expectation that knowledge } \\
\text { would be gained. }\end{array}$ & $\begin{array}{l}\text { - Curriculum is based on } \\
\text { competences derived from } \\
\text { industry needs and based on } \\
\text { endorsed national standards. } \\
\text { - Confusion is minimized } \\
\text { because all terms are used } \\
\text { nationally. }\end{array}$ & $\begin{array}{l}\text { - Assurance that : } \\
\text { - learners gain competencies of } \\
\text { recognized national standard } \\
\text { - competencies reflect need } \\
\text { - there is consistency in awards } \\
\text { - Learners' rate of progress } \\
\text { hinges on competency. }\end{array}$ \\
\hline
\end{tabular}

\section{B. Higher Order Thinking Skills (HOTS)}

A comprehensive definition written by Smith (1992) and Zohar and Dori (2002) in [10] described that HOTS is a thinking process, which consists of complicated procedures and needs to be based on various skills such as analysis, synthesis, comparison, inference, interpretation, assessment, and inductive and deductive reasoning to be employed to solve unfamiliar problems.
Referring to revised Bloom's taxonomy, HOTS includes the six levels of learning objectives: remembering, understanding, applying, analyzing, evaluating and creating process. However the development of HOTS emphasis much was placed on analyzing, evaluating and creating [11]. The description for each learning objective of six levels represents the dimension of cognitive process from simple to complex or from Lower to Higher Order Thinking Skills as depicted by Anderson and Krathwol (2001) in [12] with modifications in Figure 1.



Figure 1: The Description of Six Levels of Learning Objectives based on Bloom's Taxonomy

Reference [10] categorizes HOT into three types. First, analytical thinking, which is the ability of individuals to classify objects logically, assessing the relationships of certain elements, how they contribute, how they relate to each other, how they work, and what the most important parts are. Second, critical thinking which is the ability to evaluate and 
consider things by searching for reliable and sufficient information before making decisions, solving problems, evaluating situations and taking action on any tasks with the most appropriate and accurate ways. Third, creative thinking, which is refer to thinking competency in using previous knowledge to create new knowledge for discovering or innovating new things. This often results in more valuable outcomes, which can be used or applied to "problem solving" effectively..

HOTS is not a clear-crystal concept, therefore to clarify the concept in teaching context Fisher in [13:142] write characteristics comparison between teaching in Higher-order Thinking versus Ordinary or Routine one as shown in Table 1.

TABLE 4. Higher-order Thinking (HOT) versus Routine Teaching

\begin{tabular}{ll}
\hline \multicolumn{1}{c}{ HOT } & \multicolumn{1}{c}{ Routine Teaching } \\
\hline Not routine/not fully known in advance & Routine/outcome planned in advance \\
Complex & Clear purpose and goal \\
Yields multiple solutions/view points & Yields converging outcomes \\
Involves uncertainty & Seeks certainty \\
Involves process of making meaning & Involves process of doing \\
Is effortful, requires mental work & Is judged by outcome rather than effort \\
\hline
\end{tabular}

Globalization and the development of information technologies drive people to be creative and innovative in order they lead in global competition. Reference [14] the key success factors in this very high competitive era are creativity and innovation. Referring to Bloom taxonomy, creativity and innovation are categorized as HOTS.

A quasi-experiment research done by [15] under the title "The Effectiveness of Higher Order Thinking Skills for Generating Idea among Technical Students in Malaysia" concluded that the HOTS has a positive impact on student achievement either overall or five evaluation criteria in ideas generation after controlling control variables gender, academic achievement, SES, learning styles and mean scores of pre individual assignment. This findings support the research done by [16] that teaching and learning of HOTS enable students to be aware of their own thinking skills and using it while generating idea which is needed in global competition as well as collaboration.

The finding above should aware VTET stakeholders, especially educational decision makers and teacher that vocational and technical students need to be taught for HOTS to improve their performance on those tasks. Teachers need to possessed ability to design and execute teaching HOTS together with subject matter using the integrated approach have been implemented in the school system. However, research done by [17] explained that a self-instructional manual can be an alternative approach because it can cater to the more extendable individual differences of learner's abilities, interest and degrees of application. Therefore, students should be assisted to acquire HOTS. It can be done through the conventional teaching and learning environment or a self- instructional, individualized manual for generating idea.

\section{The Implementation of CBI}

Article 15 of Indonesia National Education System explains that vocational education (SMK) is an education at middle level that prepares the students especially for working in certain field or occupation [18]. In addition, Director of Vocational Empowerment, stated that SMK graduates are prepared for being entrepreneur [19]. In line with research findings done by [16] above, these graduates should be assisted to acquire HOTS: analyzing, critical, and creative skills to process the collected information for generating an idea.

Currently, MOEC is implementing a new competencybased curriculum formulated in 2013 known as 2013 curriculum. This curriculum was designed to respond global challenges as explained above. Regulation of Minister of Education and Culture Number 104 year 2014 describes that SMK graduates are to possess competence standards with articulation of HOTS [20]. As a consequence, SMK teachers are to have ability to articulate HOTS in teaching vocational and technical subject matters. This teaching approach will facilitate students to be active, participative, initiative, creative, independent, and responsible. Teaching-learning process needs to be based on inquiry /discovery learning to foster students to solve riel day-life problems. Students need to be taught by problem-based learning approaches both individually as well as in team or group [20].

Furthermore, 2013 curriculum also requires teachers to shifts their teaching approaches from traditional principles to new principles, especially: (1) shifting from students receiving information to students seeking themselves the information; (2) teacher is not the only the learning resource, students may learn from other resources; (3) use scientific approach that consists of five steps student's activities: observing, questioning, practicing, analyzing, and communicating; (4) shifting from learning for content to learning for competent; (5) learning partially to learning holistically; (6) balancing hard skills and soft skills; (7) utilize discovery/inquiry learning, project-based learning, and problem-based learning.

In evaluation of student learning outcomes, 2013 curriculum requires competency-based assessment or criteriabased assessment approaches. Students assessment has also referred to "authentic assessment" that relates to solving day to day riel life problems. Those types of assessment are, especially, project-based, problem-based, portfolio, and selfassessment. The 2013 Curriculum also mandates that the assessment types selected by a teacher need to be 
synchronized with teaching objectives, teaching strategies and procedures, and teaching media. All those things are written and described in his/her lesson plan.

An Indonesian study in SMK Yogyakarta done by (21) indicates that, in term of planning, lesson plans made by teachers have matched 2013 curriculum format, however the content of lesson plans mostly have not accommodated yet indicators of HOTS. For example, operational verbs used in writing learning objectives, analysis skills used in determining basic competences, and teaching-learning sequences arranged and strategies used. Those things have not matched yet with HOTS indicators. In term of teaching implementation, based on observation, teachers have also executed teaching and learning process based on their lesson plans written above, it means that they have not yet executed HOTS principles. In term of student assessment, it indicated that question verbs used in summative exam just required students to memorize, comprehended, and apply what teaching material taught about. Hence, teachers had not yet assessed student learning achievement covering HOTS characteristics.

A similar study done by [22] reported that teachers have implemented scientific approach and students have accomplished HOTS activities, however the instrument used in this study does not represent the characters of HOTS. The study also reported that teachers have executed problem solving type of assessment, even though that assessment was actually categorized as an application one.

\section{Implication to $S M K$}

Reference [11] described that HOTS may seem easy for some students, but difficult for others. It involves doing something new with the facts, understanding them, infer for them, connect them or other facts and concepts, categorize and manipulate and put them together in a new way. Furthermore, [11] characterizes HOTS as complex concept, self regulative, meaningful, nuanced judgments, uncertainty, multiple criteria as well as multiple providing solutions. However, the fact that HOTS can be learned and developed by frequently practice it.

In the context of Design and Technology, according to [11] teaching HOTS should cover: (1) using its character: analytical, critical, and creative, for example: imagination, pursuing purposes, being original, being of value. HOTS should be the best way to prepare students become future employees who are critical, innovators, and problem solvers.

Other detailed study on effectiveness of HOTS for generating idea among technical student done by [15] reveals that students taught HOTS had a positive impact on student achievement in ideas generation, after controlling variables gender, academic achievement, socio economic status (SES), and learning style, than those were not taught HOTS. Therefore, the current issue, is not whether HOTS bears benefit to students, but how teacher teach HOTS effectively to vocational and technical students. Responding this challenge, King et al. (2011) in [11] suggested that lesson involving HOTS requires particular clarity of communication to reduce ambiguities and confusion, and improve student's attitudes about thinking tasks. Then, Thomas \& Thorne in [11:39] suggested the following five foci.
First, Concepts which is an idea around which a group of ideas revolve a mental representation of a group of facts or ideas that are formally and informally related. Students should be taught to build concepts, as concepts helps in organizing thinking. Second, schemas which are simply a pattern or arrangement of knowledge that an individual has already stored in the brain that helps them understand new information. Integrating this into higher order thinking lessons would help students to infer about a particular thing based on the information they have gathered previously. Third, metaphors which refer to an abstract or unfamiliar by showing how the abstract or unfamiliar shares characteristics with a particular object, idea or concept. Fourth, visualization which refers to visual images as pictures in the mind that are equally as meaningful as or more meaningful than words. Visualization is a very useful instrument for developing HOTS, hence students should be taught to visualize in order developing the desired thinking skills that teachers long for. Fifth, inference which refers to simply means to draw conclusion, to conclude from presenting evidence. It implies reaching conclusion from a set of facts.

\section{E. Conclusion and Recommendation}

Based on discussion above, the following conclusions are presented. First, HOTS benefit for students to be critical thinking, creative to solve real life problems, especially for VET students HOTS prepares students to be more employability. Second, teachers as main players in teaching HOTS have to be positive aspiration to HOTS and have adequate knowledge and skills in teaching HOTS. Third, schools, community, business and industry would have technical and vocational school graduates who are creative, innovative, problem solver, and productive citizen.

Following recommendations are to be provided to teach HOTS successfully. First, teachers as managers and the doer in teaching learning process have to be trained and exposured on the application of teaching HOTS. Second, teaching and learning approaches have to be designed based on studentcentered learning principles. Students need to be conditionized in such a way so that they become active, critical, innovative, and problem solver related to day to day life in technical and vocational issues. Third, information technology facilities and educational resources needed in school, especially in classroom, have to be provided to support teaching HOTS effectively and efficiently.

\section{REFERENCES}

[1] H. Weber, B. Geldermann, R. Löffler, \& F. Bednarz. Competence-oriented vocational education and training Approaches and Experiences in Europe. Nürnberg, Germany: Research Institute for Vocational Education and Training Pub. (2015).

[2] J.W. Rojewski \& R.B. Hill. Positioning Research and Practice in Career and Technical Education: A Framework for College and Career Preparation in the 21st Century. Career and Technical Education Research, 39 (2), pp. 137-150, 2014. 
[3] K. Scwhab. The Fourth Revolution Industry in The World Economic Forum. Geneva, Swiss: WEF Pub., 2016.

[4] W.E. Blank. Handbook for Developing CompetencyBased Training Programs. New Jersey: Prentice-Hall, 1982.

[5] J.B. Carrol. A Model School Learning, Teacher College Record, Vol. 4, pp. 723-33, 1963.

[6] Carraccio C. , S. D. , R. Englander , K. Ferentz, C.Martin. Shifting Paradigms: From Flexner to Competencies. Academic Medicine: May 2002, Volume 77 - Issue 5 - p 361-367, 2002.

[7] E.S. Holmboe, L. Edgar, S. Hamstra. The Milestones Guidebook. https://www.acgme.org/ Portals/0/ MilestonesGuidebook.pdf., 2016.

[8] R.S. Sullivan. The Competency-Based-Approach to Training. Washington D.C.: USAIDS Pub. 1995.

[9] R.H. Harris, H. Guthrie, B. Hobart, and D. Lundberg. Competency-Based Education and Training. South Yarra, Australia: McMillan, 1997.

[10] P. Budsankom, T. Sawangboon, S. Damrongpanit, and J. Chuensirimongkol. Factors affecting higher order thinking skills of students: A meta-analytic structural equation modeling study. Educational Research and Reviews, Vol. 10(19), pp. 2639-2652, 10 October, 2015.

[11] C.C. Chinedu, Y. Kamin, and O. S. Olabiyi. Strategies for improving higher order thinking skills in teaching and learning of Design and Technology Education. Journal of Technical Education and Training (JTET). Vol. 7, No.2 December 2015.

[12] L.O. Wilson. A succinct discussion of the revisions to Bloom's classic cognitive taxonomy. The second principle.com/teaching.../beyond-bloom-cognitivetaxonomyrevised/ download on 20.07.2017.

[13] T.S. Yen \& S.H. Halili. Effective Teaching Of HigherOrder Thinking (HOT) In Education. The Online Journal of Distance Education and e-Learning, Volume 3, Issue 2. 2015.

[14] K. J. Wheelihan. (2011). Creativity for success.
[Online]. Available. http:// EzineArticles.com/

[15] Yee et al. The Effectiveness of Higher Order Thinking Skills for Generating Idea among Technical Students. Recent Advances in Educational Technologies. Available: eprints.uthm. edu.my/7448/1/yee_mei_heong_U.pdf.

[16] N. S. Rajendran, Teaching and Acquiring HigherOrder Thinking Skills Theory \& Practice. Tanjong Malim Perak: Penerbit Universiti Pendidikan Sultan Idris, 2008.

[17] J. Hoseinifar, M. M. Siedkalan, S. R. Zirak, M. Nowrozi, A. Shaker, E. Meamar, and E. Ghaderi, "An investigation of the relation between creativity and five factors of personality in students," Procedia Socialand Behavioral Sciences, vol. 30, pp. 2037-2041, 2011.

[18] Republik Indonesia. Undang-Undang Republik Indonesia Nomor 20 Tahun 2003 Tentang Sistem Pendidikan Nasional. Jakarta: Departemen Pendidikan nasional.

[19] Republik Indonesia, Direktorat Pembinaan Sekolah Menengah Kejuruan. Renstra 2014-2019. Jakarta: Depdikbud.

[20] Republik Indonesia, Peraturan Meteri Pendidikan dan Kebudayaan Nomer 104 Tahun 2014 tentang Penilaian hasil Belajar oleh Pendidik. Jakarta: Depdikbud.

[21] Jaedun A. (2014). Kesiapan Guru SMK Program Keahlian Teknik Bangunan Di Daerah Istimewa Yogyakarta dalam Mengimplemen-tasikan Kurikulum 2013. Yogyakarta. Unpublished Study.

[22] Desy E. W., Alimufi A. (2015). Implementasi Pembelajaran Scientific Approach dengan Soal Higher Order Thinking Skill pada Materi Alat-Alat Optik Kelas $X$ di SMA Nahdlatul Ulama' 1 Gresik. Unpublished study. 